\title{
IMPLEMENTASI PERAN, TUGAS DAN TANGGUNG JAWAB DINAS TERHADAP PELAKU USAHA MIKRO, KECIL, DAN MENENGAH PADA DINAS PERDAGANGAN, PERINDUSTRIAN, KOPERASI, DAN UKM DI KOTA SINGKAWANG
}

\author{
Ismail Umar 1), Sunarsih ${ }^{2)}$, \& Desvira Zain ${ }^{3)}$ \\ 1,2, ${ }^{3}$ Politeknik Negeri Pontianak \\ ${ }^{1}$ email: ismailumar79@yahoo.com
}

\begin{abstract}
Abstrak
Penelitian ini hanya dibatasi pada peran pihak dinas terkait dalam hal ini Dinas Pemda terhadap Pelaku Usaha Mikro, Kecil dan Menengah pada Dinas Perdagangan, Industri, Koperasi dan Usaha Kecil terhadap Usaha Mikro, kecil dan Menengah di kota Singkawang. Dalam hal ini selaku penulis menekankan pada implementasi keberpihak pihak dinas terhadap pelaku Usaha Mikro, pelaku koperasi terhadap perkembangan Usahanya yang berada di Kota Singkawang. Penelitian ini akan dilakukan dengan menggunakan metode penelitian Kualitatif. Metode penelitian kualitatif merupakan penelitian yang menghasilkan data deskriptif dan tidak menghasilkan data statistik atau pengukuran dalam suatu penelitian. Adapun informan yang dipilih dalam penelitian ini terkait dengan Implementasi Perkembangan Keberpihakan Pelaku Usaha Mikro, Kecil Dan Menengah Pada Dinas Perdagangan, Industri, Koperasi Dan Usaha Kecil Dikota Singkawang Kalbar. Teknik pengumpulan data merupakan tata cara yang digunakan peneliti untuk mengumpulkan datadata yang diperlukan terkait dengan penelitian yang akan dilakukan oleh peneliti. Teknik yang digunakan ada tiga, yaitu observasi, wawancara dan studi dokumentasi. Dalam Implementasi perkembangan keberpihakan dinas terhadap pelaku usaha mikro, kecil dan menengah pada dinas perdagangan, perindustrian, koperasi dan UKM di kota singkawang pada masing-masing bidang memiliki peran, tugas, dan tanggung jawab yang berbeda tetapi memiliki tujuan yang sama, tujuan utama dibentuknya Dinas Perdagangan, Perindustrian, Koperasi dan UKM Kota Pontianak ini adalah untuk memberikan pembinaan dan melakukan pengawasan kepada pelaku usaha mikro, kecil, dan menengah.
\end{abstract}

Kata Kunci: Implementasi, Dinas Usaha Mikro Kecil dan Menengah, Kota Singkawang

\section{PENDAHULUAN}

Salah satu bentuk Organisasi ekonomi rakyat bangsa Indonesia adalah Koperasi. Bagi intelektual bangsa Indonesia yang berideologikan kerakyatan yang sesuai dengan amanat dari UUD 1945 tentu koperasi merupakan organisasi yang cocok bagi bangsa Indonesia. Koperasi sebagai organisasi ekonomi rakyat yang selanjutnya dikembangkan dalam unit usaha sangat memungkinkan membantu pertumbuhan demokrasi ekonomi yang merupakan cita-cita Tokoh bangsa Indonesia dalam mensejahterakan masyarakat tanah air yang tercinta ini. Dari suatu pandangan umum koperasi yang berasal dari perkataan "co" dan "operation", yang berarti mengandung makna kerja sama untuk mencapai tujuan. Menurut pendapat Arifinal Chaniago, koperasi Indonesia, (1979:1) Pengertan koperasi adalah "Suatu perkumpulan yang beranggotakan orang-orang atau badanbadan, yang memberikan kebebasan masuk dan keluar sebagai anggota; 
dengan bekerja sama secara kekeluargaan menjalankankan usaha, untuk mempertinggi kesejahteraan jasmaniah para anggotanya".

Dalam pelaksanaannya terlihat secara kasat mata bahwa koperasi di tanah air Indonesia sejalan dengan rekomendasi yang telah dikeluarkan oleh organisasi sosial ekonomi mengenai pelaksanaan organisasi koperasi dalam membangun sosial ekonomi dan mengusulkan pihak pemerintah terkait untuk memmberikan dorongan yang tinggi untuk pengembangan organisasi swadaya masyarakat tersebut.

Begitu pentingnya membangun koperasi, menurut Hendar dan Kusnadi (2002; 4)

"Pola pembangunan koperasi pada saat awal kemerdekaan dilakukan dengan dua pola yang memiliki sasaran yang sama yaitu menciptakan koperasi sebagai organisasi otonom. Pola umum dilakukan dengan cara menyerahkan sepenuhnya kepada masyarakat dalam mendirikan dan mengelola koperasi. Pola ini sesuai dengan hakikat koperasi, yakni koperasi harus dibangun oleh mereka yang mempunyai kebutuhan sama, memdirikan perusahaan bersama dan mengelola bersama-sama. Sedangkan pola pemerintah dilakukan dengan cara pemerintah mensponsori berdirinya koperasi dan mengawasi terus perkembangan koperasi tersebut hingga mampu mencapai mandiri."

Bermula dari pendapat tersebut idealnya bahwa koperasi selayaknya memberikan kontribusi yang besar dalam membantu perekonomian masyarakat tersebut dengan kemandiriannya dan dukungan dari pihak pemerintah. Bahkan pihak pemerintah sebagai pihak pengawas yang berperan aktif mulai dari awal berdiri sampai dengan pencapaian secara mandiri. Dengan demikian koperasi memberikan harapan yang begitu tinggi bagi sebagai organisasi swadaya yang otonom, demokratisasi ekonomi bagi masyarakat serta secara singkatnya dengan adanya pergerakan koperasi yang kuat akan memberikan keyakinan kepada pihak pemerintah untuk menggalang perekonomian nasional secara tangguh dan mandiri.

Dalam suatu pembahasan tertentu tentang koperasi dimana sebagai suatu landasan berpikir yang begitu kuat secara hukumnya yang dikemukakan dalam Undang- Undang Nomor 25 Tahun 1992 yang menyatakan bahwa : (a) Koperasi, baik sebagai gerakan ekonomi rakyat maupun sebagai badan usaha berperan serta untuk mewujudkan masyarakat yang maju, adil dan makmur berdasarkan Pancasila dan Undang-Undang Dasar 1945 dan dalam tata perekonomian nasiona yang disusun sebagai usaha bersama berdasarkan atas asas kekeluargaan dan demokrasi ekonomi; (b) Koperasi perlu membangun dirinya untuk menjadi kuat dan mandiri berdasarkan prinsip koperasi sehingga mampu berperan sebagai sokoguru perekonomian nasional.

Landasan ini memberikan kedudukan yang kuat bagi koperasi Indonesia sebagai pilar pembangunan ekonomi nasional. Pada tingkat pemerintahan kab/kota di Indonesia, pemerintah dalam hal ini Dinas Perdagangan, Industri, Koperasi dan Usaha Kecil sangat memberi warna terhadap perkembangan koperasi di Tanah Air. Artinya, kepedulian mereka terhadap koperasi harus terus ditingkatkan agar koperasi di daerah itu bisa maju dan berkembang dengan baik. Jika pemerintahnya dalam hal ini dari Dinas yang terkait tidak begitu perduli tentang pentingnya berkoperasi dalam meningkatkan perekonomian nasional, bagaimana mungkin generasi milenial bisa tertarik untuk menjalankan koperasi dengan kuat dan mandiri. Salah satu daerah yang berkembang yang menarik bagi penelian ini adalah Koperasi yang 
ada di kota singkawang yang pada saat ini mengalami perkembangan semakin meningkat dari waktu ke waktunya, hal ini tampak secara sekilas adanya campur tangan dari peran pemerintah daerah khususnya dari dinas terkait. Sehingga penelitan ini ingin menelusuri bagaimana peran pemerintah daerah dalam hal ini Pemerintah Kota Singkawang dalam "Implementasi Perkembangan Keberpihakan Dinas terhadap Pelaku Usaha Mikro, Kecil dan Menengah apda Dinas Perdagangan, Perindustrian, Koperasi dan UKM di Kota Singkawang “.

Penelitian ini berusaha membahas 3 (tiga) aspek penting yang relevan dengan imlemntasi Perkembangan Keberpihakan Dinas terhadap Pelaku Usaha Mikro, Kecil dan Menengah apda Dinas Perdagangan, Perindustrian, Koperasi dan UKM di Kota Singkawang yaitu sebagai berikut:

a. Apakah unit usaha Mikro, Kecil dan Menengah mendapatkan dukungan dari pihak Dinas Perdagangan, Industri, Koperasi dan Usaha Kecil di Kota Singkawang ?

b. Sampai sejauh mana Manajemen Pelayanan yang diberikan oleh pihak Dinas terhadap Pelaku Usaha Mikro, Kecil dan Menengah Pada Dinas Perdagangan, Industri, Koperasi dan Usaha Kecil di Kota Singkawang?

c. Bagaimana Implementasi Perkembangan Keberpihakan Dinas Pemda terhadap Pelaku Usaha Mikro, Kecil dan Menengah Pada Dinas Perdagangan, Industri, Koperasi dan Usaha Kecil di kota Singkawang?

\section{METODE PENELITIAN}

Penelitian ini akan dilakukan dengan menggunakan metode penelitian Kualitatif. Metode penelitian kualitatif merupakan penelitian yang menghasilkan data deskriptif dan tidak menghasilkan data statistik atau pengukuran dalam suatu penelitian. Penelitian kualitatif biasanya digunakan untuk penelitian sosial. Dimana proses penelitian tersebut mampu menghasilkan uraian dalam bentuk tulisan, ucapan atau perilaku orang yang diamati baik dari (individu, kelompok, dan atau masyarakat), organisasi tertentu dan lain-lain.

Subjek penelitian merupakan orangorang yang dipilih peneliti sebagai sumber informasi yang dibutuhkan dalam pengumpulan data penelitian. Dalam penelitian kualitatif, subjek penelitian juga disebut informan. Penulis memilih beberapa informan berdasarkan pengetahuan yang mereka miliki mengenai objek penelitian agar dapat memberikan informasi yang diinginkan sesuai dengan tujuan penelitian. Adapun informan yang dipilih dalam penelitian ini terkait dengan Implementasi Perkembangan Keberpihakan Pelaku Usaha Mikro, Kecil Dan Menengah Pada Dinas Perdagangan, Industri, Koperasi Dan Usaha Kecil Dikota Singkawang Kalbar. Adapun pihak-pihak yang diperlukan sebagai informan yakni:

a. Pihak Pimpinan (Kepala Bidang) Dinas Kantor Perdagangan, Industri, Koperasi dan Usaha Kecil Kota Singkawang selaku informan pertama.

b. Pihak penanggung jawab pembinaan koperasi kota Singkawang.

c. pihak pengelola koperasi yang berhasil mengembangkan koperasi.

\section{Teknik Pengumpulan Data}

Teknik pengumpulan data merupakan tata cara yang digunakan peneliti untuk mengumpulkan data-data yang diperlukan terkait dengan penelitian yang akan dilakukan oleh peneliti. Teknik yang digunakan ada tiga, yaitu observasi, wawancara dan studi dokumentasi. Adapun teknik pengumpulan data yang digunakan dalam penelitian ini adalah sebagai berikut: 


\section{a. Observasi}

Observasi merupakan teknik pengumpulan data yang tidak hanya melihat dari sikap responden namun dapat digunakan juga untuk merekam berbagai kejadian baik situasi maupun kondisi yang ada.

\section{b. Wawancara}

Wawancara adalah teknik pengumpulan data untuk mendapatkan informasi dengan melakukan tanya jawab secara langsung maupun tidak langsung (media komunikasi) kepada responden. Responden yang digunakan dalam penelitian ini merupakan pelaku usaha UKM Kota Singkawang.

\section{c. Studi Dokumentasi}

Dokumentasi merupakan teknik pengumpulan data yang dilakukan secara tidak langsung yang ditujukan kepada subjek yang akan diteliti dalam rangka memperoleh informasi terkait objek penelitian.

\section{Teknik Analisis Data}

Analisis data berlangsung secara bersama-sama dengan proses pengumpulan data dengan alur tahapan sebagai berikut:

\section{a. Reduksi Data.}

Data yang diperolah ditulis dalam bentuk laporan atau data yang terperinci. Laporan yang disusun berdasarkan data yang diperoleh direduksi, dirangkum, dipilih hal-hal yang pokok, difokuskan pada hal- hal yang penting.

\section{b. Penyajian Data}

Data yang diperoleh dikategorisasikan menurut pokok permasalahan dan dibuat dalam bentuk matriks sehingga memudahkan peneliti untuk melihat polapola hubungan satu data dengan data lainnya.

\section{c. Penyimpulan dan Verifikasi Kegiatan \\ Penyimpulan merupakan langkah lebih lanjut dari kegiatan reduksi dan penyajian data.}

\section{HASIL DAN PEMBAHASAN}

Dalam Implementasi perkembangan keberpihakan dinas terhadap pelaku usaha mikro, kecil dan menengah pada dinas perdagangan, perindustrian, koperasi dan UKM di kota singkawang pada masingmasing bidang memiliki peran, tugas, dan tanggung jawab yang berbeda tetapi memiliki tujuan yang sama, tujuan utama dibentuknya Dinas Perdagangan, Perindustrian, Koperasi dan UKM Kota Pontianak ini adalah untuk memberikan pembinaan dan melakukan pengawasan kepada pelaku usaha mikro, kecil, dan menengah.

Tujuan dari penelitian ini, peran Dinas Perdagangan, Perindustrian, Koperasi dan UKM Kota Singkawang sangatlah kuat baik di pengawasan pengendalian pelaksanaan Implementasi terhadap industri kecil menengah dan juga melakukan pembinaan yang berupa turun langsung ke lokasi, hal inilah yang ingin peneliti ketahui lebih jauh.

Untuk mendapatkan informasi peneliti mewawancarai beberapa informan yang terkait langsung dalam melakukan peran mereka dalam mendukung kegiatan usaha Mikro, Kecil dan Menengah dan mengawasi kegiatan pelaku usaha bahkan bentuk implementasi pengembangan keberpihkan Dinas Pemda terhadap pelaku usaha Mikro, Kecil dan Menengah.

Peran Dinas terkait dalam memberikan dukungan pada pelaku usaha mikro, kecil dan menengah di kota singkawang

Berdasarkan Undang-Undang Republik Indonesia Nomor 3 Tahun 2014 tentang Perindustrian yang menyatakan bahwa, "Pengawasan dan Pengendalian 
yang sebagaimana dimaksud dilakukan untuk mengetahui pemenuhan dan kepatuhan terhadap peraturan di bidang perindustrian yang dilaksanakan oleh perusahaan industry dan perusahaan kawasan industri”.

Pada pembahasan ini dapat penulis simpulkan bahwa pada implementasi perkembangan keberpihakan dinas terhadap pelaku usaha mikro, kecil dan menengah pada dinas perdagangan, perindustrian, koperasi dan UKM di kota singkawang memiliki peranan yang berbeda-beda pada setiap bidang. Untuk bidang Koperasi dan UKM memiliki peran sebagai pihak pelaksana yang menindak lanjuti tugas yang telah sesuai dengan peraturan-peraturan dari kementerian koperasi dan usaha kecil menengah dalam melakukan pengawasan dan pembinaan dalam memberikan sanksi menonaktifkan koperasi-koperasi yang tidak sesuai dan tidak memiliki nomor induk koperasi (NIK) dan berperan untuk melakukan pembinaan dan pengawasan kepada koperasi-koperasi yang tidak memberikan laporan triwulan dalam waktu dua tahun berjalan maka koperasi tersebut dapat langsung dinonaktifkan. Untuk bidang Perdagangan memiliki peranan sebagai pihak pelaksana dalam melakukan pengawasan terkait barangbarang beredar dilingkungan perdagangan di Kota Singkawang sebagai pihak pelaksana bidang perdagangan akan melakukan pengawasan kepada barangbarang yang inport maupun eksport dan melihat apakah barang edaran tersebut sudah memiliki sertifikasi halal dari MUI ataupun memastikan barang edaran tidak kadaluwarsa. Sedangkan untuk Bidang Perindustrian memiliki peranan sebagai pihak pelaksana yang bertanggung jawab dalam memberikan pembinaan kepada pelaku usaha mengenai bagaimana cara dalam melakukan pengembangan serta mengelolahterkait dengan barang atau produk yang akan diedarkan atau diperjualbelikan.

Dari kesimpulan diatas dapat diketahui bahwa setiap bidang pada Dinas Perdagangan, Perinsdustrian, Koperasi dan UKM Kota Singkawang memiliki peranan yang berbeda-beda dalam melaksanaan pengawasan dan pembinaan kepada pelaku usaha mikro, kecil, dan menengah Kota Singkawang.

\section{Konsep tentang apa yang dapat dilakukan oleh individu dalam masyarakat sebagai organisasi}

Pada indikator ini penulis akan membahas mengenai bagaimana peran dari pihak pelaksana dalam menyusun kerangka kerja guna mempermudah pelaku usaha mikro, kecil, dan menengah Kota Singkawang. Dari hasil wawancara yang penulis lakukan kepada beberapa informan dalam menanyakan peranan beliau dalam memberikan dukungan pada usaha Mikro, Kecil dan Menengah, sehingga mendapat jawaban yang relevan dan akurat.

Pertanyaan "Bagaimana peran Dinas Perdagangan, Industri, Koperasi, dan Usaha Kecil Kota Singkawang dalam menyusun kerangka kerja atau persyaratan dalam proses pelayanan tarkait pelaku usaha mikro, kecil, dan menengah pada Kota Singkawang”.

Jawaban Infoman 1 (Kepala Bidang Koperasi dan UKM)

"Disini menggunakan Sistem ODS (Online Data System) dengan sistem ini mempermudah untuk mengakses kegiatan koperasi yang ada di Kabupaten Kota dan ditinjau langsung oleh pihak Kementerian. Disini juga mengunakan sistem yang dinamakan sistem sertifikat NIK koperasi dimana jika koperasi yang sudah terdaftar dan sudah berbadan hukum maka kita akan dapat membuatkan sertifikat NIK koperasi, tetapi untuk menerbitkan 
sertifikat yang memiliki NIK koperasi ini juga ada syaratnya. Syarat pertama koperasi yang bersangkutan harus dapat dikatakan aktif dalam arti melaksanakan RAC sesuai dengan perundang-undangan. Untuk mengeluarkan sertifikan NIK masih perlu banyak data harus di lengkap, seperti NPWP koperasi, memiliki keanggotaan yang lengkap, pembukuan harus tertata rapi.Kelemahan dari koperasi ini hanya pada Sumber Daya Manusia nya saja.Untuk persyaratan UMKM kita hanya mengikuti program yang di buat oleh Gubernur Kalbar yang disebut UKM naik Kelas dalam arti usaha mikro menjadi usaha menengah, usaha menengah menjadi usaha besar.Disini terdapat kendala untuk kita melakukan monitoring dalam segi pembinaan disini bisa dikatakan agak sulit, kalau koperasi memiliki badan hukum sendiri dan pembinaannya dapat langsung dilakukan pada bidang koperasi.Kalau UKM pelaku usaha informaldimana pada UMKM ini bisa saja terdapat pelaku usaha yang berdagang sesuai dengan mood mereka dan UKM ini untuk membubarkannya sangat mudah karena itu semua tergantung dengan bagaimana mereka menjual produk mereka dan UMKM ini tidak memiliki badan hukum".

Jawaban Informan 2 (Kepala Bidang Perdagangan dan Kasi Distribusi dan Perdagangan Luar Negeri)

"disini kita tidak ada persyaratan administrasi kerena pelimpahan wewenang dalam mengeluarkan izin itu sudah menjadi tanggung jawab OPD lain, disini kita hanya mengandalkan atau menggunakan surat tugas yang dimana jika surat tugas tersebut sudah diberikan ataupun sudah keluar maka akan mudah bagi kita untuk melanjutkan tindakan pengawasan terhadap pelaku usaha".

Berdasarkan hasil wawancara yang penulis lakukan pada informan 1 dan informan 2 pada Dinas Perdagangan,
Perindustrian, Koperasi dan UKM Kota Singkwangdapat penulis simpulkan bahwa peranan masing-masing bidang dalam menyusun kerangka kerja guna mempermudah pelaku usaha mikro, kecil, dan menengah Kota Singkawang pada Bidang Koperasi dan UKM guna mempermudah melakukan pemantauan terkait koperasi-koperasi yang tidak memiliki NIK (Nomor Induk Koperasi) dan memantau langsung kegiatan dalam memberikan laporan triwulan pada Dinas Perdagangan, Perindustrian, Koperasi dan UKM Kota Singkawang. Sedangkan pada Bidang Perdagangan dan Kasi Distribusi dan Perdagangan Luar Negeri tidak memiliki kerangka kerja yang dianggap dapat mempermudah pelaku usaha mikro, kecil, dan menengah, hal itu dikarenakan dalam melaksanakan peran dari bidang mereka hanya memerlukan surat tugas untuk melanjutkan paran mereka sebagai pihak yang melakukan pengawasan kepada pelaku usaha mikro, kecil, dan menengah Kota Singkawang.

\section{Untuk mengetahui Manajemen Pengawasan yang diberikan oleh Dinas terkait dalam melayani pelaku usaha Mikro, kecil dan menengah di Kota Singkawang}

Pada bab ini penulis akan membahas mengenai bagaimana manajemen pengawasan yang diberikan oleh Dinas Perdagangan, Perindustrian, Koperasi dan UKM Kota Singkawang terkait pelaku usaha mikro, kecil, dan menengah yang ada di Kota Singkawang. Untuk membahas lebih lanjut mengenai bagaimana manajemen pengawasan yang diberikan Disperindagkop Kota Singkawang kepada pelaku usaha penulis menggunakan teori Fitrianingrum (2015:148) pengawasan memiliki beberapa indikator, yaitu:

1. Kesesuaian pengawasan dengan rencana 
2. Kesesuaian pengawasan dengan pimpinan dan pegawainya

3. Penyimpangan dalam pengawasan

4. Objektivitas pengawasan

5. Fleksibelitas pengawasan

6. Hemat dalam pengawasan

7. Mengadakan tindakan perbaikan

Untuk Mengetahui Sampai Sejauh Mana Implementasi Perkembangan Keperbihakan Dinas Perdagangan, Perindustrian, Koperasi dan UKM Kota Singkawang Pada Pelaku Usaha Mikro, Kecil dan Menengah Di Kota Singkawang

Pada bab ini penulis akan membahas mengenai sejauh mana implementasi perkembangan keperbihakan Dinas Perdagangan, Perindustrian, Koperasi dan UKM Kota Singkawang Pada Pelaku Usaha Mikro, Kecil dan Menengah Di Kota Singkawang. Untuk membahas lebih lanjut mengenai bagaimana manajemen pengawasan yang diberikan Disperindagkop Kota Singkawang kepada pelaku usaha penulis menggunakan teori dari Van Metter dan Van Horn dalam Agustino (2016:133) mengatakan bahwa ada 6 (enam) variabel yang mempengaruhi kinerja implementasi kebijakan publik, antara lain:

1. Ukuran dan tujuan kebijakan Kinerja implementasi kebijakan dapat diukur tingkat keberhasilannya jika-danhanya-jika ukuran dan tujuan dari kebijakan memang realistis dengan sosio-kultur yang mengada di tingkat pelaksana kebijakan.

2. Sumber daya Keberhasilan proses implementasi kebijakan sangat tergantung dari kemampuan memanfaatkan sumber daya yang tersedia.

3. Karakteristik agen pelaksana Pusat perhatian pada agen pelaksana meliputi organisasi formal dan organisasi informal yang akan terlibat pengimplementasian kebijakan publik.

4. Sikap atau kecenderungan (Disposition) para pelaksana Sikap penerimaan atau penolakan dari (agen) pelaksana akan sangat banyak mempengaruhi keberhasilan atau tidaknya kinerja implementasi kebijakan publik.

5. Komunikasi antar organisasi dan aktivitas pelaksana Koordinasi merupakan mekanisme sekaligus syarat utama dalam menentukan keberhasilan pelaksanaan kebijakan.

6. Lingkungan ekonomi, sosial dan politik Upaya untuk mengimplementasikan kebijakan harus pula memperhatikan kekondusifan kondisi lingkungan eksternal. Hal ini juga harus diperhatikan guna menilai kinerja implementasi publik dalam perspektif yang ditawarkan oleh van Meter dan van Horn adalah sejauh mana lingkungan eksternal turut mendorong keberhasilan kebijakan publik yang telah ditetapkan.

\section{a. Ukuran dan Tujuan}

Variabel ini akan mengukur sejauh mana standar dan sasaran kebijakan ini telah dilaksanakan. Ukuran dan tujuan kebijakan sangat menentukan keberhasilan dalam pencapaian tujuan dari implementasi perkembangan keperbihakan Dinas Perdagangan, Perindustrian, Koperasi dan UKM Kota Singkawang Pada Pelaku Usaha Mikro, Kecil dan Menengah Di Kota Singkawang. Berdasarkan hasil wawancara penulis kepada informan dapat dikatahui apa yang menjadi tujuan atas keberpihakan Dinas Perdagangan, Perindustrian, Koperasi dan UKM Kota Singkawang terkait dengan pelaku usaha mikro, kecil, menengah Kota Singkawang. 
Menurut Agustino (2017:156) menyatakan bahwa, Implementasi kebijakan dianggap tidak efektif apabila tujuan kebijakan tidak dapat dipenuhi, jika orang-orang tetap bertindak dengan cara yang tidak diinginkan oleh maksud kebijakan, jika subjek kebijakan tidak memakai cara yang ditentukan oleh kebijakan, atau pun jika subjek kebijakan berhenti mengerjakan apa yang ditentukan. Dapat di lihat dari penjelasan dibawah bahwa terdapat beberapa hal yang mengakibatkan satu implementasi kebijakan dikatakan efektif atau tidak.

a. Respek Anggota Masyarakat Pada Otoritas dan Keputusan Pemerintah.

b. Kesadaran Untuk Menerima Kebijakan.

c. Ada atau Tidaknya Sanksi Hukum.

d. Kepentingan Pribadi atau Kelompok.

e. Bertentangan Dengan Sistem Nilai yang Ada.

f. Keanggotaan Seseorang atau Sekelompok Oran dalam Suatu Organisasi.

g. Wujudnya Kepatuhan Selektif.

Pertanyaan "Apa tujuan Dinas Perdagangan, Industri, Koperasi, dan Usaha Kecil dalam Implementasi perkembangan keberpihakan Dinas Pemda terhadap apelaku usaha mikro, kecil dan menengah di Kota Singkawang?

Jawaban informan 1 dan informan 2 (Kepala Bidang Perdagangan dan Kepala Bidang Koperasi dan UKM)

"Tujuan nya untuk melakukan sosialisasi dan pemahaman kepada palaku usaha agar pelaku usaha dapat membedakan mana barang edaran yang layak diperjual belikan mana yang tidak. Jangan sampai pada saat realisasi pada kegiatan pengawasan masih ditemukan barang edaran yang tidak layak diperjual belikan kepada masyarakat umum.

Kenapa kita harus melakukan pengawasan, hal itu dikarenakan kota singkawang ini cukup dekat dengan perbatasan dan tak jarang banyak barang dari luar seperti dari Malaysia yang masuk dan diperjual belikan dan disini pelaku usaha tidak melihat lagi apakah barang tersebut sudah kadarluasa atau belum banyak pelaku usaha hanya mempehatikan harga, karena barang Malaysia yang masuk ke Indonesia ini dijual dengan harga murah maka banyak mengundang minat pelaku usaha untuk menjual produk luar dibandingkan produk yang di produksi di kota singkawang ini."

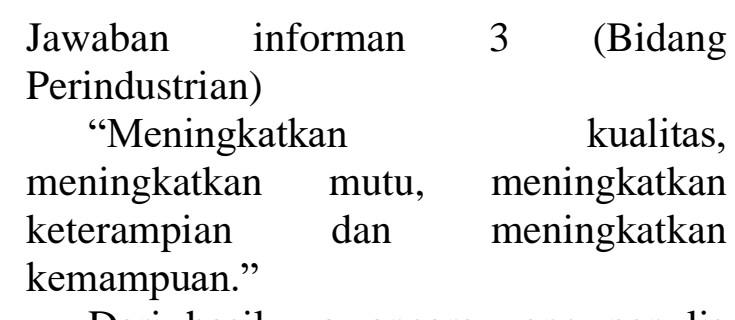

Dari hasil wawancara yang penulis lakukan bersama informan dapat penulis simpulkan tujuan dari masing-masing bidang dalam Implementasi perkembangan keberpihakan Dinas Perdagangan, Perindustrian, Koperasi dan UKM Kota Singkawang terkait pelaku usaha mikro, kecil, menengah di Kota Singkawang hanya sebatas memberikan bantuan pendanaan kepada pelaku usaha yang dilakukan Bidang Perindustrian tidak hanya memberikan bantu tetapi juga memberikan pembinaan kepada pelaku usaha industri di Kota Singkawang dalam meningkatkan kemampuan dan keterampilan pada pelaku usaha, sedangkan Bidang Perdagangan memiliki tujuan memberikan pengawasan langsung kepada pelaku usaha mikro, kecil, dan menengah di Kota Singkawang, sedangkan untuk Bidang Koperasi dan UKM juga melakukan pengawasan tetapi pengawasan yang dilakukan hanya berupa pengawasan kepada pelaporan keuangan terkait kemajuan atau perkembangan dari pendapatan yang didapatkan oleh pelaku usaha Koperasi dan UMK di Kota Singkawang. 


\section{b. Sumber Daya}

Dalam suatu kebijakan faktor sumber daya juga mempunyai peran penting dalam keberhasilan dari implementasi perkembangan keperbihakan Dinas Perdagangan, Perindustrian, Koperasi dan UKM Kota Singkawang Pada Pelaku Usaha Mikro, Kecil dan Menengah Di Kota Singkawang. Ketersediaan sumber daya yang mencukupi dalam implementasi perkembangan keperbihakan Dinas Perdagangan, Perindustrian, Koperasi dan UKM Kota Singkawang Pada Pelaku Usaha Mikro, Kecil dan Menengah Di Kota Singkawang merupakan salah satu faktor yang harus selalu diperhatikan. manusia merupakan sumber daya terpenting dalam keberhasilan sebuah implementasi kebijakan. Pada proses implementasi perkembangan keperbihakan Dinas Perdagangan, Perindustrian, Koperasi dan UKM Kota Singkawang Pada Pelaku Usaha Mikro, Kecil dan Menengah Di Kota Singkawang sangat membutuhkan sumber daya manusia yang berkualitas dan yang memiliki keahlian serta kemampuan dalam melakukan pengawasan dan pembinaan pada pelaku usaha mikro, kecil dan menengah Kota Singkawang. Tidak hanya itu sumber daya juga terdiri dari sumber daya waktu dan sumber daya material, yang dimaksud dengan sumber daya waktu adalah dalam sebuah implementasi perkembangan keperbihakan Dinas Perdagangan, Perindustrian, Koperasi dan UKM Kota Singkawang Pada Pelaku Usaha Mikro, Kecil dan Menengah Di Kota Singkawang pembuat kebijakan harus dapat memperkirakan waktu yang tepat agar waktu tersebut akan mudah untuk direalisasikan jika waktu yang diberikan tidak sesuai maka sulit untuk mencapai keberhasilan dari implementasi perkembangan keperbihakan Dinas Perdagangan, Perindustrian, Koperasi dan
UKM Kota Singkawang Pada Pelaku Usaha Mikro, Kecil dan Menengah Di Kota Singkawang tersebut dan untuk mengukur keberhasilan dari implementasi perkembangan keperbihakan Dinas Perdagangan, Perindustrian, Koperasi dan UKM Kota Singkawang Pada Pelaku Usaha Mikro, Kecil dan Menengah Di Kota Singkawang pembuat kebijakan juga harus memperhatikan sarana dan prasarana yang digunakan yang dimaksud dengan sarana yaitu seperti fasilitas yang diberikan kepada masyarakat apakah sesuai dengan kebutuhan dan prasarana apakah tempat yang disediakan juga sesuai implementasi perkembangan keperbihakan Dinas Perdagangan, Perindustrian, Koperasi dan UKM Kota Singkawang Pada Pelaku Usaha Mikro, Kecil dan Menengah Di Kota Singkawang.

Pertanyaan "Siapa yang bertanggung jawab atas pelaksanaan proses pengawasan yang diberikan kepada pelaku usaha mikro, kecil dan menengah di Kota Singkawang?"

Jawaban Informan 1 (Kepala Bidang Koperasi dan UKM)

"Yang bertanggung yaa pasti orangorang yang ditunjuk untuk melakukan pengawasan, Kepala Dinas Perdagangan, Perindustrian, Koperasi dan UKM Kota Singkawang, Bidang Koperasi, Penyuluh pemeriksaan koperasi Lapangan dari Kementerian, Ketua Koperasi terbesar di Kota Singkawang, dan pelaku-pelaku koperasi yang melaporkan."

Pertanyaan "Berapa jumlah staf yang berada pada Dinas Perdagangan, Industri, Koperasi, dan Usaha Kecil yang terlibat dalam Implementasi perkembangan keberpihakan palaku usaha mikro, kecil dan menengah?" 
Jawaban informan 2 (Kepala Bidang Perdagangan)

"khusus bidang perdagangan ini kita sebagai pihak pelaksana pengawasan barjumlah 6 orang biasanya itu juga akan kita bagi menjadi tiga kelompok atau tim yang kemudian kita gabungkan dengan dinas-dinas yang terkait pada pelaksanaan pengawasan ini."

Jawaban informan 3 (Kepala Bidang Perindustrian)

"Ada 6 termaksud pak kabid semua staf di bidang industri"

Dari hasil wawancara yang penulis lakukan kepada informan maka dapat disimpulkan bahwa pada masing-masing sudah memiliki jumlah staf yang bertanggung jawab dalam pelaksanaan keberpihakan dari Dinas Perdagangan, Perindustrian, Koperasi dan UKM Kota Singkawang terkait pelaku usaha mikro, kecil dan menengah Kota Singkawang.

Menurut metter and horn (2017:38-39) menyatakan bahwa, "Sumber-sumber daya lain yang perlu diperhitungkan juga ialah sumber daya financial dan waktu. Sumber daya waktu. Saat sumber daya manusia giat bekerja dan kecuran dana berjalan dengan baik, tetapi terbentuk dengan masalah waktu yang terlalu ketat, maka hal ini pun dapat menjadi penyebab ketidak berhasilan suatu implementasi kebijakan."

Dapat diketahui bahwa untuk mencapai keberhasilan dari implementasi kebijakan pihak pelaksana juga harus melihat berapa lama waktu yang dibutuhkan untuk menyelesaikan seluruh kegiatan pengawasan terkait Implementasi perkembangan keberpihakan Dinas Perdagangan, Perindustrian, Koperasi dan UKM Kota Singkwang terkait dengan pelaku usaha mikro, kecil, dan menengah di Kota Singkawang. Untuk mengetahui berapa lama waktu pada pelaksanaan kebijakan tersebut maka penulis menanyakan beberapa pertanyaan sebagai berikut.

Pertanyaan "Apakah Dinas Perdagangan, Industri, Koperasi, dan Usaha Kecil Kota Singkawang sudah memberikan kepastian waktu dalam menyelesaikan proses pengawasan tersebut?"

Jawaban informan 1 (Kelapa Bidang Koperasi dan UKM)

"waktu yang dibutuhkan pada pelaksanaan pengawasan ini tergantung berapa lama dari pelaku usaha memberikan laporan triwulan, dalam jangka waktu kurang lebih 2 tahun pelaku usaha tidak memberikan laporan kemajuan mereka maka kita sebagai pihak pelaksana akan melakukan pengawasan dan pembinaan dan lama waktu yang dibutuhkan paling lama 3 hari jika tidak terjadi kendala seperti dana"

Jawaban informan 2 (Kepala Bidang Perdagangan)

"yang jelas setiap kita melakukan pengawasan dan pengendalian waktu yang kita gunakan itu hanya tiga hari kerja saja, lebih dari itu kita akan memprosesnya dengan kegiatan selanjutnya atau di bulan selanjutnya."

Jawaban informan 3 (Kepala Bidang Perindustrian)

"Berdasarkan ketentuan, saya minta dengan kawan tu minimal 3 tahun secara mengajukan, dan menyesuaikan dengan kemampuan keuangan kita, tapi program ini bisa juga disampaikan oleh warga melalui musrembang kelurahan, atau musrembang kecamatan di bahas di musrembang kota. kalau tidak ada di dalam musrembang itu misalnya di industry kecil menengah mana atau home indutri mana yang pengajuan waktu musrembang tingkat kelurahan atau tingkat kecamatan itu tidak ada itu bisa juga dan di dalam musrembang tingkat 
kota itu tidak ada program ajuan" sarana prasarana ataupun alat" dari kelompok IKM itu, bisa juga berbasis ajuan proposal langsung dari kelompok usaha Ajukan ke kita, kita sortir pelajari kebenaran proposal itu akan kita ajukan ke program itu."

Dari hasil wawancara diatas dapat disimpulkan bahwa untuk bidang perdagangan hanya membutuhkan waktu 3 hari untuk menyelesai seluruh kegiatan pengawasan terkait pelaku usaha mikro, kecil dan menengah Kota Singkawang pengawasan tersebut dilakukan dengan cara membagi tim kerja karena untuk melakukan pengawasan terkait barang edaran perlu membutuhkan tenaga kerja dan kerja sama yang baik agar seluruh kegiatan dapat berjalan sesuai dengan tujuan awal, untuk Bidang Koperasi dan UKM waktu yang dibutuhkan pada pengawasan dan pembinaan juga 3 hari kerja, pengawasan dilakukan tidak setiap bulan hal itu dikarenakan sarana dan prasana yang di fasilitasi pemerintah daerah masih sangat minim untuk meminimalisir hal tersebut Dinas Perdagangan, Perindustrian, Koperasi dan UKM Kota Singkawang hanya melakukan pengawasan dan pembinaan jika pelaku usaha koperasi dan UKM Kota Singkawang tidak memberikan Laporan Kemajuan selama kurang lebih 2 tahun berturut-turut, dan untuk Bidang Perindustrian kerena bertanggung jawab memberikan bantuan dan pembinaan kepada pelaku usaha indstri kecil dan menengah (IKM) maka untuk memproses pelaksaan dalam memberikan bantuan kepada pelaku usaha IMK bidang perindustrian membutuhkan waktu lebih dari 3 tahun lamanya hal tersebut dikarenakan Bidang Perindustrian harus mendapat laporan dari perkembangan/kemajuan dari Bidang Koperasi dan UKM atau bisa langsung dari pelaku usahanya, jika pelaku usaha IKM dapat menunjukan laporan kemajuannya dan usaha meraka dinyatakan sesaui dengan standar yang sudah ditetapkan maka Bidang perindustrian akan melanjutkan berkas permohonan bantuan dana tersebut. Tetapi jika usaha tersebut di nilai tidak memiliki kemajuan maka bidang industri akan memberikan pembinaan langsung kepada pelaku usaha mengenai alasan usaha mereka tidak dapat berkembang dengan baik

\section{SIMPULAN}

Berdasarkan hasil penelitian yang dilakukan dapat penulis simpulkan mengenai bagaimana peran dinas dalam memberikan dukungan pada pelaku usaha mikro, kecil, dan menengah, manajemen pengawasan, dan implementasi perkembangan keberpihakan Dinas terkait pelaku usaha mikro, kecil, dan menengah pada Kota Singkawang sebagai berikut:

1. Bidang perindustrian pada Dinas Perdagangan, Perindustrian, Koperasi, UKM Kota Singkawang terkait memberikan dukungan pada pelaku usaha mikro, kecil, dan menengah di Kota Singkawang yaitu dengan melakukan pengawasan dan pembinaan berdasarkan UU No. 3 tahun 2014 tentang perindustrian terhadap pelaku usaha untuk memperbaiki kualitas industry pelaku usaha agar tidak melakukan penyelewengan terutama pada bidang perindustrian dimana keberpihakan bidang perindustrian berhubungan dengan sertifikat higenis, sertifikat produk pangan industri rumah tangga, edukasi baik secara langsung maupun tidak langsung dan memberikan fasilitas kepada pelaku usaha berupa sarana dan prasana. Kemudian untuk bidang perdagangan memiliki peranan sebagai pihak pelaksana pengawasan atau bidang yang bertanggung jawab untuk melakukan monitoring terkait 
pelaku usaha perdagangan di Kota Singkawang, pengawasan khususnya pada barang-barang yang beredar seperti pengawasan barang bersubsidi. Pengawasan tersebut berdasarkan dengan peraturan perundang undangan yang telah ditentukan yaitu undang undang nomor 32 tahun 2011. Tujuan dilakukannya pengawasan ini hanya untuk melakukan pengendalian dan kemudian akan diberikan arahan atau sosialisasi kepada pelaku usaha terkait dengan bagaimana barang beredar yang dapat dijual belikan, yang terakhir Bidang Koperasi dan UKM yang memiliki peranan sebagai pihak pelaksana untuk melakukan pengawasan dan pengendalian tetapi pengendalian dilakukan Ketika mendapat laporan dari pelaku usaha, dan pengendalian dilakukan ketika tidak mendapatkan laporan triwulan dari pihak koperasi, dan berperan sebagai pihak yang menindaklanjuti dari peraturan yang sudah dibuat oleh kementerian koperasi dan usaha kecil menengah yaitu untuk memberhetikan koperasi-koperasi yang dianggap tidak sesuai atau tidak terdapat nomor induk koperasi. Pengawasan Koperasi berdasarkan peraturan pemerintah nomor 17 tahun 2013 tentang pelaksanaan undang undang nomor 20 tahun 2008.

2. Berdasarkan hasil wawancara yang penulis lakukan, dapat penulis simpulkan bahwa Pelaku Usaha Mikro, Kecil dan Menengah Pada Dinas Perdagangan, Industri, Koperasi dan Usaha Kecil di kota Singkawang terdapat kendala yang sama pada masing masing bidang yaitu berupa sumber daya seperti sumber daya manusia, sumber daya finansial, sarana dan prasarana dan sumber daya waktu. Kemudian kendala yang ada pada bidang perdagangan juga tidak bisa menyita barang-barang yang melenggar peraturan seperti barang yang tidak layak untuk diperjual dan di beli.

Dengan informasi yang diperoleh keberpihakan masing-masing bidang baik bidang Perindustrian, Perdaganngan dan Koperasi membantu dalam upaya meningkatkan secara kuantitas para pelaku Usaha Kecil dan Menengah dalam peran sertanya dibidang ekonomi kota Singkawang baik dalam bidang Administrasi dan operasionalnya, baik dalam bentuk pelatihan dan fasilitas serta finansial yang dibutuhkan oleh pelaku Usaha Kecil dan Menengah tersebut.

\section{REFERENSI}

Arikunto Suharsimi. EdisiRevisi. 2010. Prosedur Penelitian, Suatu Pendekatan Praktik. Penerbit PT. Rineka Cipta.

Hendardan Kusnadi, Edisi Revisi 2002. Ekonomi Koperasi. Lembaga Penerbit Fakultas Ekonomi Universitas Indonesia.

Herabudin, 2016, Studi Kebijakan Pemerintah, dari Filosofi ke Implementasi, Penerbit Pustaka Setia, Bandung.

Muhibudin, Zaenal Mukarom, 2018, Manajemen Pelayanan Publik, Pengantar Pustaka, Bandung.

Pusat Bahasa Departemen Pendidikan Nasional. 2003. Kamus Besar Bahasa Indonesia Edisi Ketiga.Balai Pustaka, Jakarta.

SunindhiaY.W, Ninik Widiyanti, 2003, Koperasi dan Perekonomian Indonesia, Penerbit Rineka Cipta dan Bina Adiaksara, Jakarta.

Sritua Arief, 2002, Ekonomi Kerakyatan Indonesia: Bung Hatta, Bapak Ekonomi Kerakyatan Indonesia, Univeristas Muhammadiyah, Surakarta. 
Sugiyono.2012. Metode Penelitian

Kuantitatif, Kualitatif, dan $R \& D$.

Alfabeta, Bandung.

Syafiie, I. K. 2011. Manajemen

Pemerintahan. Pustaka Reka Cipta, Bandung.

Tahir, A. 2015. Kebijakan Publik dan

Transparansi Penyelenggaraan

Pemerintahan Daerah. Alfabeta,

Bandung.

Fitrianingrum, Eva Dila. 2015. Pengaruh

Pengawasan Terhadap Disiplin Kerja

Pegawai Pada Kantor Kecamatan

Samarinda Ulu Kota Samarinda.

eJournal Administrasi Negara. III (5):

MDCXLIV-MDCLV

Syafiie, Kencana Ibnu. 2019. Ilmu

Manajemen. Pustaka Reka Cipta.

Bandung.

Implementasi Peran, Tugas, dan Tanggung Jawab Dinas terhadap Pelaku Usaha Mikro, Kecil, dan Menengah pada Dinas Perdagangan, Perindustrian, Koperasi dan UKM di Kota Singkawang 